\title{
Effect of exogenous indolbutiric acid (IBA) applications and cuttings collection times on rooting capacity of sweet tamarind
}

\author{
Antonio Flávio Arruda Ferreira ${ }^{1 \star}$, Marcela Sant'anna Cordeiro da Silva ${ }^{2}$, Laís Naiara Honorato Monteiro ${ }^{3}$, \\ Mariane Jerônimo Forte ${ }^{4}$, Glaucia Amorim Faria ${ }^{4}$, Maria Gabriela Fontanetti Rodrigues ${ }^{5}$ and Aparecida \\ Conceição Boliani ${ }^{4}$
}

\author{
${ }^{1}$ Mato Grosso State University, Alta Floresta, MT, Brazil. \\ ${ }^{2}$ University of São Paulo, Piracicaba, SP, Brazil. \\ ${ }^{3}$ São Paulo State University, Botucatu, SP, Brazil. \\ ${ }^{4}$ São Paulo State University, Ilha Solteira, SP, Brazil. \\ ${ }^{5}$ São Paulo State University, Dracena, SP, Brazil. \\ *Author for correspondence: arrudaferreira.af@gmail.com
}

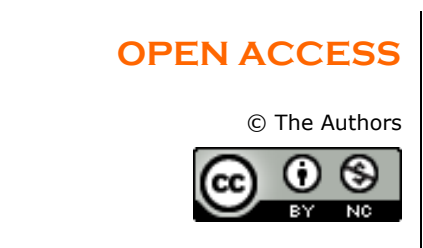

Submitted on November 05, 2018 Accepted on July 19, 2019 Early View on July 30, 2019 Final Publication on July 31, 2019

Authors declare no conflict of interest KEYWORDS: Tamarindus indica Propagating material Propagation Tropical fruit

\section{ABSTRACT}

Considering its adaptation to tropical countries, sweet tamarind (Tamarindus indica L., Fabaceae) has been gaining space in the food and pharmaceutical industry due to its nutraceutical richness. The lack of research on the propagation of non-traditional tropical fruits has been a barrier to the production of large-scale seedlings and to the availability of products in the food and pharmaceutical markets. Thus, the objective of this experiment was to evaluate the influence of collection periods and exogenous indolbutiric acid (IBA) concentrations on rooting of softwood, semi-hardwood and hardwood sweet tamarind cuttings, aiming the production of seedlings. For this, cuttings with $18 \mathrm{~cm}$ length were collected in winter and spring, being planted in polyethylene trays filled with medium texture vermiculite. The experiment was conducted in a greenhouse of Pad\&Fan type with temperature and controlled humidity. The experimental design was completely randomized in a factorial design (2 collection times $\times 3$ types of cuttings $\times 5$ concentrations of IBA) with four replicates of 10 cuttings. After 90 days, the following variables were evaluated: the percentage of rooted cuttings and dead cuttings; root number; length of the largest root $(\mathrm{cm})$; and shoot number. It was observed that soft-wood cuttings had a higher rhizogenic capacity, influenced by the collection season, with winter being the best time. The highest percentage of dead cuttings was observed in semi-hardwood and hardwood cuttings, both when collected in winter and in spring. The number of roots in soft-wood cuttings was higher in the $1,500 \mathrm{mg}$ $\mathrm{kg}^{-1}$ concentration of exogenous IBA and when collected in winter this material also showed a higher number of shoots. It can be concluded that sweet tamarind softwood cuttings harvested in winter and treated with $1,500 \mathrm{mg} \mathrm{kg}^{-1}$ of exogenous IBA support the percentage of rooted cuttings, number of roots and shoots, showing a better rhizogenic capacity.

\section{Highlighted Conclusion}

The use of $1,500 \mathrm{mg} \mathrm{kg}^{-1}$ of exogenous IBA favors the rooting capacity of sweet tamarind softwood cuttings collected in the winter season.

\section{INTRODUCTION}

The tree of sweet tamarind (Tamarindus indica L., Fabaceae) is known for its versatility, extremely adapted in tropical climate, gaining space in food and drug industries due to its flavour and nutraceutical properties. In addition, the mesocarp presents high concentration of vitamin $C$ and is widely used in industrial manufacture of jams, juices and ice creams. Moreover, fruits and plant extracts present many medicinal properties, such as antifungal, anti-inflammatory, anti-spasmodic and anti-diabetic (Martinello et al. 2006; Amado et al. 2012; Garcia et al. 2012; Razali et al. 2015; Reis et al. 2016; Okello et al. 2017).

The long vegetative period of plants derived from seeds, which is a common practice for growing seedlings of sweet tamarind, impairs market supply chain. Yet the extractive use and management of sweet tamarind fruits are maintained. 
Thus, plant propagation methods from cuttings allow seedlings production. Such method anticipates production and brings uniformity to plants, since they will be genetically identical to the parental plant, besides reducing vegetative period. According to Ferreira et al. (2017), this method will anticipate sweet tamarind production in 3 to 4 years, that is, an attempt to prolong their availability for fresh consumption and industrialization, as well as transforming the extractive system into a commercial one.

However, the success in cuttings will also depend on genetic and environmental factors to increase seedling production, as the whole process can be directly affected by external and internal factors, intrinsically related to the plant matrix and its nutritional and physiological conditions (Park et al. 2017).

With regards to the environment, choosing a collection period is essential for a better distribution of seedling production around the year. According to Pivetta et al. (2012), the determination of the best season provides greater rooting capacity, as long as availability, material needed, and propagule regenerative capacity are analysed.

The collection period is closely related to material type to be obtained and its lignification degree (Pizzatto et al. 2011). The same authors also mention that cuttings collected in periods of more intense vegetative growth are softwood, that is, greater rooting capacity as compared to hardwood and lignified material obtained in rest period. With regard to the physiological conditions, the viability of cuttings has increased with plant regulators, which provide an endogenous hormonal balance suitable for the rhizogenesis process, especially between auxins, gibberellins and cytokinins, enabling adventitious roots formation (Park et al. 2017; Daskalakis et al. 2018). Therefore, the exogenous application of plant regulators can be used to balance hormones, mainly indolebutyric acid (IBA), bearing in mind that the ideal concentration varies according to the species (Daskalakis et al. 2018).

Given all the above, this study aimed to evaluate exogenous IBA concentrations on rooting of softwood, semihardwood and hardwood cuttings of sweet tamarind collected in spring and winter.

\section{MATERIAL AND METHODS}

The experiment took place at the orchard of Faculty of Engineering (FEIS), São Paulo State University (UNESP), in Ilha Solteira, Brazil. This orchard is located at the geographical coordinates of $20^{\circ} 25^{\prime} 24.4^{\prime \prime} \mathrm{S}$ and $51^{\circ} 21^{\prime} 13.1^{\prime \prime} \mathrm{W}$, $337 \mathrm{~m}$ of elevation. The climate of this area is classified as tropical with dry winter (Aw), according to Köppen. (1948).

Plant material was purchased from a private orchard located in the city of Ilha Solteira, SP, Brazil, and the cuttings of sweet tamarind trees (Tamarindus indica L.) were collected in the spring and winter of 2014.

Softwood (Figure 1A) and semi-hardwood cuttings (Figure 1B) were used with two pairs of leaves; while hardwood cuttings (Figure 1C) with a length of $18 \mathrm{~cm}$. The base of each cutting was soaked in deionised water. Afterwards, they were dipped into a fine powder of IBA (Dynamic ${ }^{\circledR}$ ) at 0 (only fine powder), 500; 1,000; 1,500 and $2,000 \mathrm{mg} \mathrm{kg}^{-1}$. Subsequently, the propagation material was staked in black polypropylene boxes, filled with medium vermiculite.

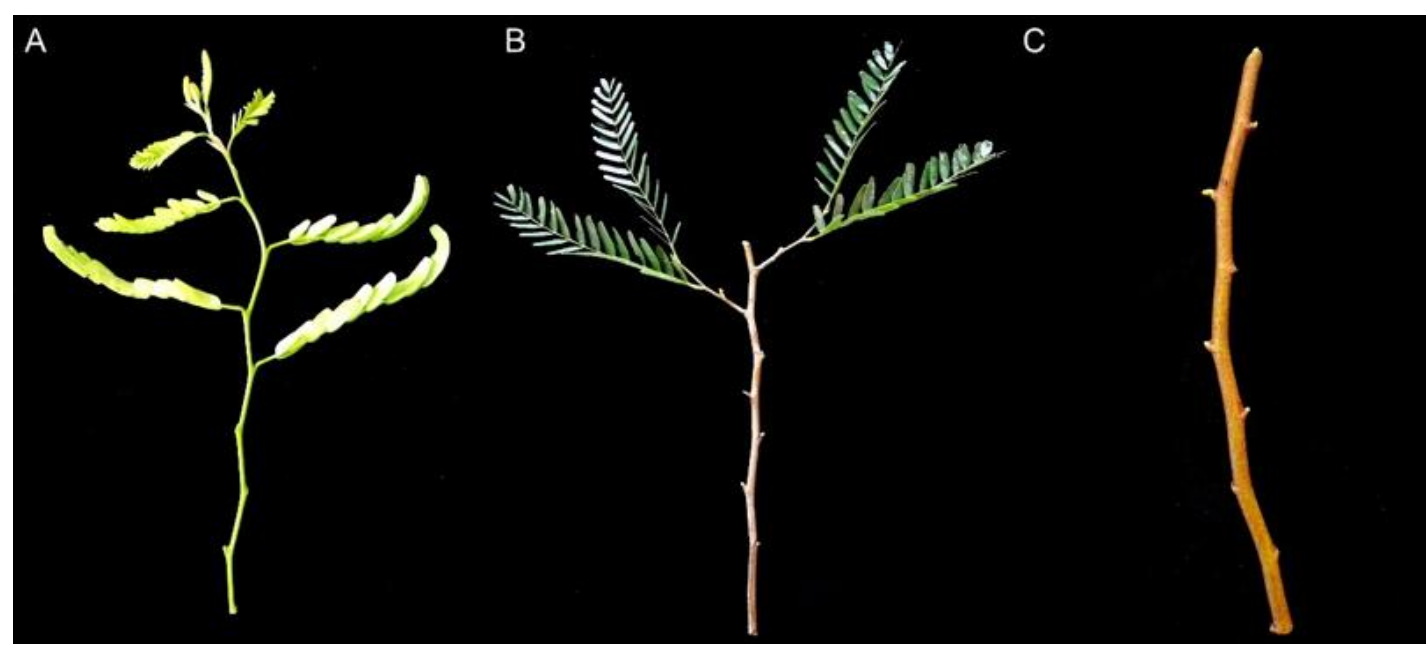

Figure 1. Softwood (A), semi-hardwood (B) and hardwood (C) cuttings of sweet tamarind trees.

The experiment was installed in a greenhouse, which was ventilated by forced air system (Pad\&Fan), besides fan and pad system for evaporative cooling. The greenhouse was covered with $50 \%$ shade cloth (with a thermocouple attached to it), in addition to temperature controlled at $28 \pm 2{ }^{\circ} \mathrm{C}$. Irrigation was performed five times daily for 5 minutes (flow rate of $1,800 \mathrm{~L} \mathrm{~min}^{-1}$ ). 
After 90 days, the following variables were analysed: the percentage (\%) of rooted cuttings $(\mathrm{RC})$ and dead cuttings (DC); root number (RN); length of the largest root (LLR) (cm); and shoot number (SN).

The experiment was conducted in a completely randomized design in the factorial scheme $[2 \times 3 \times 5$ (collection times $x$ cutting types $x$ IBA concentrations)] with 4 replicates and 10 cuttings per replicate. Data were submitted to analysis of variance by $F$ test, and the differences between mean were determined by Tukey test, using the software SISVAR $5.6^{\circledR}$.

\section{RESULTS AND DISCUSSION}

A significant difference in the triple factor interaction for CR, RN and LLR is observed in the F test (Table 1). For the DC variable a significant reduction in the death of the cuttings in the spring period is observed. In the spring for the $\mathrm{SN}$ variable there was also a significant difference for interaction between periods and type of cuttings (Table 1).

Table 1. Percentage of rooted cuttings (RC) and dead cuttings (DC), root number (RN) and length of the largest root (LLR) and shoot number (SN) of sweet tamarind cuttings collected in periods and treated with IBA concentrations.

\begin{tabular}{|c|c|c|c|c|c|}
\hline \multirow{2}{*}{ Source of variation } & $\mathrm{RC}(\%)$ & $\mathrm{DC}(\%)$ & $\mathrm{RN}$ & $\operatorname{LLR}(\mathrm{cm})$ & SN \\
\hline & \multicolumn{5}{|c|}{ Mean Square } \\
\hline Periods $(\mathrm{P})$ & $367.50^{*}$ & $2000.83^{*}$ & $3.71^{*}$ & $32.76^{*}$ & $69.77^{*}$ \\
\hline Cuttings (C) & $367.50^{*}$ & $65.83^{N S}$ & $3.71^{*}$ & $32.76^{*}$ & $15.01^{*}$ \\
\hline IBA & $40.41^{\mathrm{NS}}$ & $65.42^{\mathrm{NS}}$ & $0.75^{\star}$ & $4.36^{* \star}$ & $4.26^{\mathrm{NS}}$ \\
\hline$P \times C$ & $367.50^{*}$ & $65.83^{\mathrm{NS}}$ & $3.71^{*}$ & $32.76^{*}$ & $15.01^{*}$ \\
\hline$P \times I B A$ & $40.42^{\mathrm{NS}}$ & $65.42^{\mathrm{NS}}$ & $0.75^{*}$ & $4.36^{\star *}$ & $4.26^{\mathrm{NS}}$ \\
\hline $\mathrm{C} \times \mathrm{IBA}$ & $40.42^{\star *}$ & $61.67^{\mathrm{NS}}$ & $0.75^{\star}$ & $4.36^{\star *}$ & $1.58^{\mathrm{NS}}$ \\
\hline $\mathrm{P} \times \mathrm{C} \times \mathrm{IBA}$ & $40.42^{* *}$ & $61.67^{\mathrm{NS}}$ & $0.75^{\star}$ & $4.36^{\star *}$ & $1.58^{\mathrm{NS}}$ \\
\hline \multicolumn{6}{|l|}{ Periods } \\
\hline Spring & $0.00 \mathrm{~B}^{1}$ & $100.00 \mathrm{~A}$ & $0.00 \mathrm{~B}$ & $0.00 \mathrm{~B}$ & $0.00 \mathrm{~B}$ \\
\hline Winter & $3.50 \mathrm{~A}$ & 91.83 B & $0.35 \mathrm{~A}$ & $1.05 \mathrm{~A}$ & $1.53 \mathrm{~A}$ \\
\hline \multicolumn{6}{|l|}{ Cuttings } \\
\hline Softwood & $5.25 \mathrm{~A}$ & 94.50 & $0.53 \mathrm{~A}$ & $1.57 \mathrm{~A}$ & $0.08 \mathrm{~B}$ \\
\hline Semi-hardwood & $0.00 \mathrm{~B}$ & 96.25 & $0.00 \mathrm{~B}$ & $0.00 \mathrm{~B}$ & $1.25 \mathrm{~A}$ \\
\hline Hardwood & $0.00 \mathrm{~B}$ & 97.00 & $0.00 \mathrm{~B}$ & $0.00 \mathrm{~B}$ & $0.96 \mathrm{AB}$ \\
\hline \multicolumn{6}{|l|}{ IBA } \\
\hline 0 & 0.83 & 95.83 & $0.04 \mathrm{~B}$ & 0.25 & 0.92 \\
\hline 500 & 2.92 & 95.41 & $0.17 \mathrm{AB}$ & 0.99 & 0.52 \\
\hline 1000 & 2.92 & 94.58 & $0.23 \mathrm{AB}$ & 0.45 & 0.69 \\
\hline 1500 & 2.08 & 95.00 & $0.45 \mathrm{~A}$ & 0.92 & 1.40 \\
\hline 2000 & 0.00 & 98.75 & $0.00 \mathrm{~B}$ & 0.00 & 0.29 \\
\hline C.V. (\%) & 250.17 & 6.52 & 240.45 & 249.74 & 225.39 \\
\hline
\end{tabular}

It was observed that the IBA concentrations in 500; 1,000 and $1,500 \mathrm{mg} \mathrm{kg}^{-1}$ did not differ among them, presenting the highest percentage of softwood cuttings rooted in the winter period (Table 2). These values also differed and were superior when compared to the semi-hardwood and hardwood cuttings in the same period, as well as when compared with the spring softwood cuttings.

Table 2. Percentage of rooted cuttings in softwood, semi-hardwood and hardwood cuttings of sweet tamarind, treated with different concentrations of indolebutyric acid (IBA).

\begin{tabular}{|c|c|c|c|c|c|c|}
\hline \multirow{2}{*}{$\begin{array}{l}\text { IBA } \\
\left(\mathrm{mg} \mathrm{kg}^{-1}\right)\end{array}$} & \multicolumn{3}{|c|}{ Winter } & \multicolumn{3}{|c|}{ Spring } \\
\hline & Softwood & $\begin{array}{c}\text { Semi- } \\
\text { hardwood }\end{array}$ & Hardwood & Softwood & $\begin{array}{c}\text { Semi- } \\
\text { hardwood }\end{array}$ & Hardwood \\
\hline 0 & $5.00 \underline{a} \mathrm{BC} \mathrm{a}^{*}$ & $0.00 \underline{a} \mathrm{~A} \mathrm{a}$ & $0.00 \underline{a} \mathrm{~A} a$ & $0.00 \underline{b} \mathrm{~A} a$ & $0.00 \underline{a} \mathrm{~A} \mathrm{a}$ & $0.00 \underline{a} \mathrm{~A} a$ \\
\hline 500 & $17.50 \underline{a} \mathrm{~A} a$ & $0.00 \underline{a} \mathrm{~A} \mathrm{~b}$ & $0.00 \underline{a} \mathrm{~A} \mathrm{~b}$ & $0.00 \underline{b} \mathrm{~A} \mathrm{a}$ & $0.00 \underline{a} \mathrm{~A} \mathrm{a}$ & $0.00 \underline{a} \mathrm{~A} a$ \\
\hline 1,000 & $17.50 \underline{a} \mathrm{~A} a$ & $0.00 \underline{a} \mathrm{~A} \mathrm{~b}$ & $0.00 \underline{a} \mathrm{~A} \mathrm{~b}$ & $0.00 \underline{b} \mathrm{~A} \mathrm{a}$ & $0.00 \underline{a} \mathrm{~A} \mathrm{a}$ & $0.00 \underline{a} \mathrm{~A} a$ \\
\hline 1,500 & $12.50 \underline{a} \mathrm{AB}$ a & $0.00 \underline{a} \mathrm{~A} \mathrm{~b}$ & $0.00 \underline{a} \mathrm{~A} \mathrm{~b}$ & $0.00 \underline{b} \mathrm{~A} a$ & $0.00 \underline{a} \mathrm{~A} a$ & $0.00 \underline{a} \mathrm{~A} a$ \\
\hline 2,000 & $0.00 \underline{a} \mathrm{C} \mathrm{a}$ & $0.00 \underline{a} \mathrm{~A} a$ & $0.00 \underline{a} \mathrm{~A}$ a & $0.00 \underline{a} \mathrm{~A}$ a & $0.00 \underline{a} \mathrm{~A} \mathrm{a}$ & $0.00 \underline{a} \mathrm{~A} a$ \\
\hline
\end{tabular}


Zem et al. (2015) observed that the period of the year in which the propagation material is collected has an influence on rhizogenesis induction and may be caused due to the nutrient reserves of the exchange tissues and their activity, as well as the distribution of auxins during the seasons.

By collecting propagation material in winter, the degree of lignification and reserves accumulation are higher, which may reduce adventitious root formation capacity in certain species (Marangon and Biasi 2013). However, an opposite result was obtained in this study, even there was low rooted cuttings percentage in winter, the value obtained was higher than propagules collected in spring; consequently, winter was the most favourable for rooting of sweet tamarind tree under this study's conditions.

Softwood cuttings are more vulnerable to environmental conditions, according to Hartmann et al. (2011), due to dehydration and death, since there is a low degree of lignification and nutrient reserves that are necessary to plants development. However, softwood cuttings obtained the highest percentage of rooted cuttings and the lowest of dead cuttings in this study (Table 1).

There was a significant interaction between types of cuttings and IBA concentrations, as softwood cuttings treated with $1,500 \mathrm{mg} \mathrm{kg}^{-1}$ exogenous IBA (2.68 roots), differing statistically to the other concentrations and types of cuttings (Table 3 ).

Table 3. Root number in softwood, semi-hardwood and hardwood cuttings of sweet tamarind, treated with different concentrations of indolebutyric acid (IBA).

\begin{tabular}{|c|c|c|c|c|c|c|}
\hline \multirow{2}{*}{$\begin{array}{l}\text { IBA } \\
\left(\mathrm{mg} \mathrm{Kg}^{-1}\right)\end{array}$} & \multicolumn{3}{|c|}{ Winter } & \multicolumn{3}{|c|}{ Spring } \\
\hline & Softwood & $\begin{array}{c}\text { Semi- } \\
\text { hardwood }\end{array}$ & Hardwood & Softwood & $\begin{array}{c}\text { Semi- } \\
\text { hardwood }\end{array}$ & Hardwood \\
\hline 0 & $0.25 \underline{a} \mathrm{CD} \mathrm{a}^{*}$ & $0.00 \underline{a} \mathrm{~A} \mathrm{a}$ & $0.00 \underline{a} \mathrm{~A} \mathrm{a}$ & $0.00 \underline{a} \mathrm{~A} \mathrm{a}$ & $0.00 \underline{a} \mathrm{~A} \mathrm{a}$ & $0.00 \underline{a} \mathrm{~A} \mathrm{a}$ \\
\hline 500 & $1.00 \underline{a} \mathrm{BC} \mathrm{a}$ & $0.00 \underline{a} \mathrm{~A} \mathrm{~b}$ & $0.00 \underline{a} \mathrm{~A} \mathrm{~b}$ & $0.00 \underline{b} \mathrm{~A}$ a & $0.00 \underline{a} \mathrm{~A} \mathrm{a}$ & $0.00 \underline{a} \mathrm{~A} a$ \\
\hline 1,000 & $1.35 \underline{a} \mathrm{~B} \mathrm{a}$ & $0.00 \underline{a} \mathrm{~A} \mathrm{~b}$ & $0.00 \underline{a} \mathrm{~A} \mathrm{~b}$ & $0.00 \underline{b} \mathrm{~A} a$ & $0.00 \underline{a} \mathrm{~A} \mathrm{a}$ & $0.00 \underline{a} \mathrm{~A} a$ \\
\hline 1,500 & $2.68 \underline{a} \underline{A} a$ & $0.00 \underline{a} \mathrm{~A} \mathrm{~b}$ & $0.00 \underline{a} \mathrm{~A} \mathrm{~b}$ & $0.00 \underline{b} \mathrm{~A} a$ & $0.00 \underline{a} \mathrm{~A} \mathrm{a}$ & $0.00 \underline{a} \mathrm{~A} a$ \\
\hline 2,000 & $0.00 \underline{a} \mathrm{D} \mathrm{a}$ & $0.00 \underline{a} \mathrm{~A} \mathrm{a}$ & $0.00 \underline{a} \mathrm{~A} \mathrm{a}$ & $0.00 \underline{a} \mathrm{~A} \mathrm{a}$ & $0.00 \underline{a} \mathrm{~A} \mathrm{a}$ & $0.00 \underline{a} \mathrm{~A} \mathrm{a}$ \\
\hline Mean & 1.06 & 0.00 & 0.00 & 0.00 & 0.00 & 0.00 \\
\hline
\end{tabular}

Oliveira et al. (2009) reported that high IBA concentrations may cause plant injury (phytotoxicity), since it inhibits rhizogenesis, as well as decreases the root number, wich may have occurred in this study. However, Zem et al. (2015) stated that the effect of exogenous auxins may vary among species, that is, an optimal concentration may promote adventitious roots formation, but might cause injury in some cases.

At concentrations of 500 and $1,500 \mathrm{mg} \mathrm{kg}^{-1}$ of IBA, the highest lengths of the largest root were observed in the softwood cuttings, reaching 5.93 and $5.53 \mathrm{~cm}$, respectively (Table 4). These values were significantly different from the other types of cuttings in the winter and also when compared to the spring period. Some factors affect the quality of cuttings, since semi-hardwood and hardwood cuttings present more lignified tissues (Lima et al. 2006), in other words, physical barriers that undermine adventitious roots induction and emission. Moreover, lignification can be negatively related to endogenous auxin levels (Hartmann et al. 2011), since peroxidise (an enzyme responsible for lignin synthesis) break down auxin; thus, reducing root formation, which was observed in this study.

Leaf abscission was observed at 15 days after softwood and semi-hardwood were staked. However, the sprouting of lateral buds occurred in winter, providing 2.50 shoots in softwood and 1.93 in semi-hardwood cuttings, such values were higher than hardwood cuttings (Table 5).

Table 4. Length of the largest root in softwood, semi-hardwood and hardwood cuttings of sweet tamarind, treated with different concentrations of indolebutyric acid (IBA).

\begin{tabular}{|c|c|c|c|c|c|c|}
\hline \multirow{2}{*}{$\begin{array}{l}\text { IBA } \\
\left(\mathrm{mg} \mathrm{Kg}^{-1}\right)\end{array}$} & \multicolumn{3}{|c|}{ Winter } & \multicolumn{3}{|c|}{ Spring } \\
\hline & Softwood & $\begin{array}{c}\text { Semi- } \\
\text { hardwood }\end{array}$ & Hardwood & Softwood & $\begin{array}{c}\text { Semi- } \\
\text { hardwood }\end{array}$ & Hardwood \\
\hline 0 & $1.50 \underline{a} B C a^{*}$ & $0.00 \underline{a} \mathrm{~A} a$ & $0.00 \underline{a} \mathrm{~A} \mathrm{a}$ & $0.00 \underline{a} \mathrm{~A} \mathrm{a}$ & $0.00 \underline{a} \mathrm{~A} \mathrm{a}$ & $0.00 \underline{a} \mathrm{~A} \mathrm{a}$ \\
\hline 500 & $5.93 \underline{a} \mathrm{~A}$ a & $0.00 \underline{a} \mathrm{~A} \mathrm{~b}$ & $0.00 \underline{a} \mathrm{~A} \mathrm{~b}$ & $0.00 \underline{b} \mathrm{~A} a$ & $0.00 \underline{a} \mathrm{~A} \mathrm{a}$ & $0.00 \underline{a} \mathrm{~A} a$ \\
\hline 1,000 & $2.73 \underline{a} \mathrm{~B} \mathrm{a}$ & $0.00 \underline{a} \mathrm{~A} \mathrm{~b}$ & $0.00 \underline{a} \mathrm{~A} \mathrm{~b}$ & $0.00 \underline{b} \mathrm{~A} a$ & $0.00 \underline{a} \mathrm{~A}$ a & $0.00 \underline{a} \mathrm{~A} a$ \\
\hline 1,500 & $5.53 \underline{a} \underline{A} \mathrm{a}$ & $0.00 \underline{a} \mathrm{~A} \mathrm{~b}$ & $0.00 \underline{a} \mathrm{~A} \mathrm{~b}$ & $0.00 \underline{b} \mathrm{~A} a$ & $0.00 \underline{a} \mathrm{~A} \mathrm{a}$ & $0.00 \underline{a} \mathrm{~A} a$ \\
\hline 2,000 & $0.00 \underline{a} \mathrm{C} \mathrm{a}$ & $0.00 \underline{a} \mathrm{~A} \mathrm{a}$ & $0.00 \underline{a} \mathrm{~A} \mathrm{a}$ & $0.00 \underline{a} \mathrm{~A} a$ & $0.00 \underline{a} \mathrm{~A} \mathrm{a}$ & $0.00 \underline{a} \mathrm{~A} \mathrm{a}$ \\
\hline Mean & 3.14 & 0.00 & 0.00 & 0.00 & 0.00 & 0.00 \\
\hline
\end{tabular}


Table 5. Shoot number in softwood, semi-hardwood and hardwood cuttings of sweet tamarind in spring and winter.

\begin{tabular}{|c|c|c|c|}
\hline \multirow{2}{*}{ Collection times } & \multicolumn{3}{|c|}{ Shoot number } \\
\hline & Softwood & Semi-hardwood & Hardwood \\
\hline Winter & $2.50 \mathrm{Aa}^{*}$ & $1.93 \mathrm{Aa}$ & $0.15 A b$ \\
\hline Spring & $0.00 \mathrm{Ba}$ & $0.00 \mathrm{Ba}$ & $0.00 \mathrm{Ba}$ \\
\hline Mean & 1.38 & 1.09 & 0.28 \\
\hline
\end{tabular}

In semi-hardwood and hardwood cuttings, the best shoot development is related to a decrease in transpiration, since it enables cell differentiation in the apical parts of the cuttings and more shoot emergence, according to Paiva et al. (2015).

According to Taiz and Zeiger (2013) and Campos et al. (2015), auxin is a hormone capable of activate cambial growth and adventitious roots formation, but also stimulate ethylene synthesis and other adverse effects of excessive concentration, which can compromise rhizogenesis and aerial part growth; consequently, leading to tissue death.

Moreover, rooting capacity of cuttings were possibly affected by matrix plant's intrinsic factors, such as age; or exogenous factors, such as substrate, plant regulator concentration and environment, as they are decisive for the efficiency of this propagation method (Hartmann et al. 2011).

We conclude that sweet tamarind softwood cuttings collected in the winter and treated with $1,500 \mathrm{mg} \mathrm{kg}^{-1}$ of exogenous IBA favor the rooting percentage, number of roots and shoots.

\section{Acknowledgments}

The authors thank the São Paulo Research Foundation - FAPESP for financial support (12/12287-0).

\section{References}

Amado JR et al. 2012. Standardization of the quality control parameters of the Tamarindus indica L. soft extract. Revista Cubana de Plantas Medicinales 17:108-114.

Campos GNF et al. 2015. Clonal propagation of Cnidoscolus quercifolius by air-layering. Ciência Florestal 25:743-749.

Daskalakis I et al. 2018. The effect that indolebutyric acid (IBA) and position of cane segment have on the rooting of cuttings from grapevine rootstocks and from Cabernet franc (Vitis vinifera L.) under conditions of a hydroponic culture system. Scientia Horticulturae 227:79-84.

Ferreira AFA et al. 2017. Substrates and indolebutyric acid (IBA) concentrations in air-layering rooting of Tamarind tree. African Journal of Agricultural Research 12:2926-2932.

Garcia JCV et al. 2012. Sistemas de manejo y comercialización de tamarindo (Tamarindus indica L.) en tres municipios de Veracruz. Revista Mexicana de Ciencias Agrícolas 3:1217-1230.

Hartmann H T et al. 2011. Plant propagation: principles and practices. New Jersey, Prentice Hall.

Köppen W. 1948. Climatologia: con un estudio de los climas de la tierra. Fondo de Cultura Economica: México.1

Lima RLS et al. 2006. Size and part of the branch to be used as barbados cherry cuttings. Revista Brasileira de Fruticultura 28:83-86.

Marangon MA and Biasi LA. 2013. Cutting propagation of blueberry in seasons of the year with indolebutyric acid and bottom heat. Pesquisa Agropecuária Brasileira 48:25-32.

Martinello F et al. 2006. Hypolipemic and antioxidante activities from Tamarindus indica pulp fruit extract in hypercholesterolemic hamsters. Food and Chemical Toxicology 44:810-818.

Okello $\mathrm{J}$ et al. 2017. Mineral composition of Tamarindus indica LINN (tamarind) pulp and seeds from different agro-ecological zones of Uganda. Food Science and Nutrition 5:959-966.

Oliveira A F et al. 2009. Rooted stem cutting of the olive tree in different times, substrates and doses of IBA diluted in $\mathrm{NaOH}$ and alcohol. Ciência e Agrotecnologia 33:79-85.

Paiva EP et al. 2015. Growth and quality of seedlings pomegranate 'wonderful' propagated by cuttings. Revista Caatinga 28:64-75.

Park SL et al. 2017. Adventitious root formation of in vitro peach shoots is regulated by auxin and ethylene. Scientia Horticulturae 226:250-260.

Pivetta KFL et al. 2012. Harvesting time and indolebutyric acid on the rooting of Nerium oleander L. cuttings. Revista Árvore 36:17-23.

Pizzatto M et al. 2011. Effects of IBA concentration, collection time and cutting length on hibiscus cutting propagation. Revista Ceres 58:487492.

Razali $\mathrm{N}$ et al. 2015. Polyphenols from the extract and fraction of $T$. indica seeds protected HepG2 cells against oxidative stress. BMC Complementary Alternative Medicine 15:1-16.

Reis PMCL et al. 2016. Extraction and evaluation of antioxidant potential of the extracts obtained from tamarind seeds (Tamarindus indica), sweet variety. Journal of Food Engineering 173:116-123.

Taiz L and Zeiger E. 2013. Fisiologia vegetal. 5.ed. Porto Alegre: Artemed.

Zem L M et al. 2015. Herbaceous and semi-hardwood stem cuttings of Drimys brasiliensis. Revista Ciência Agronômica 46:396-403. 